\title{
Modeling Pathogen DNA Content and Visual Disease Assessment in Seed Tubers to Inform Disease in Potato Progeny Root, Stolon, and Tubers
}

\author{
Robert S. Tegg and Ross Corkrey, Tasmanian Institute of Agriculture, University of Tasmania, New Town Research Laboratories, New \\ Town 7008, Australia; Herdina Herdina and Alan C. McKay, South Australian Research Development Institute, Urrbrae, South Aus- \\ tralia 5064, Australia; Nigel S. Crump, ViCSPA, Healesville, Victoria 3777, Australia; Rudolf F. de Boer and Tonya J. Wiechel, De- \\ partment of Environment and Primary Industries, AgriBio Centre for AgriBiosciences; and Calum R. Wilson, Tasmanian Institute of \\ Agriculture, University of Tasmania, New Town Research Laboratories, New Town 7008, Australia
}

\begin{abstract}
Tegg, R. S., Corkrey, R., Herdina, H., McKay, A. C., Crump, N. S., de Boer, R. F., Wiechel, T. J., and Wilson, C. R. 2015. Modeling pathogen DNA content and visual disease assessment in seed tubers to inform disease in potato progeny root, stolon, and tubers. Plant Dis. 99:50-57.

Measurement of pathogens on seed tubers is essential for informing likelihood of subsequent potato disease. Here we utilized quantitative PCR assessment of pathogen DNA and visual assessment of disease to measure seed tuber inoculum and used this to model development of disease in potato grown in pathogen-free soil. Analysis by recursive partitioning and modeling using receiver operating curves indicated both abundance of Rhizoctonia solani AG3 and Streptomyces scabies DNA, and disease symptoms associated with these pathogens on seed tubers could predict subsequent disease in progeny tubers and for $R$. solani, stolons. In contrast, abundance of Spongospora subterranea

DNA and disease symptoms on seed tubers were not consistently associated with powdery scab in progeny tubers. The relationship between $S$. subterranea DNA and seed tuber symptoms on root galling was stronger. Symptomless seed tubers that carried high levels of S. subterranea DNA were also associated with greater root galling than those with low pathogen DNA levels. There was a modest association between root galling and powdery scab in progeny tubers. These results highlight the importance of using certified seed tubers, and demonstrate a statistical tool for measuring the impact of seed tuber-borne inoculum.
\end{abstract}

Potato (Solanum tuberosum L.) seed tuber certification schemes help protect growers from planting diseased tubers that can exacerbate disease in the progeny crop $(2,11)$, and are important in the production of sustainable and profitable potato crops. However, the role of seed tuber-borne inoculum and its effect on subsequent potato crop production is not fully understood.

In Australia, three major diseases affecting potato tuber production and quality are black scurf, common scab, and powdery scab $(30,32,40)$, caused by infections with the pathogens Rhizoctonia solani Kühn AG3, Streptomyces scabies (Thaxter) Lambert \& Loria, and Spongospora subterranea (Wallr.) Lagerh. f. sp. subterranea Tomlinson, respectively. These pathogens are able to survive for extended periods in soil, which provides an important inoculum source (11) along with the inoculum brought in on the seed tuber. Where planting occurs in new cropping areas free of soil contamination by these pathogens, diseased or contaminated seed tubers also play a critical role in the introduction and establishment of pathogen inoculum at these sites.

There is, however, debate as to the importance of seed tuberborne inoculum on disease in progeny plants for some of these diseases. High levels of stem and stolon disease $(3,34)$ and black scurf $(3,8,34)$ in progeny has consistently been associated with planting seed tubers containing high levels of $R$. solani. However, with common scab and powdery scab, there is evidence for either increased $(10,22,38,39)$ or unchanged levels of disease in progeny tubers following planting infected tubers $(1,6,16,19)$. Transmission of the pathogen from infected seed tubers to progeny tubers does not appear to be straightforward in the case of powdery scab (5), with other factors including cultivar (13) and environmental conditions (28) impacting on disease progress and expression. While

Corresponding author: R. Tegg, E-mail: Robert.Tegg@utas.edu.au

Accepted for publication 5 July 2014.

http://dx.doi.org/10.1094/PDIS-04-14-0337-RE

(C) 2015 The American Phytopathological Society tuber disease has been the focus of most studies with $S$. subterranea in potato, root infection leading to gall production is another significant disease $(22,28)$, resulting in poor growth and reduced yields (10). The relationship between seed tuber-borne pathogen inoculum and root gall production has not been studied in detail. Further study is required to better elucidate the role of seed tuberborne inoculum on $S$. subterranea induced disease in both progeny roots and tubers.

Recent innovations in PCR based technologies have enabled detection, differentiation, and quantitation of specific pathogens $(4,24,33)$ from both soil and seed tuber peel. Commercial soil tests are now available that quantify specific pathogens and provide a threshold risk analysis for planting potato tubers into these soils; such tests are available for black dot (20), root knot nematode (24), and powdery scab $(5,24)$. Prior to this study, these commercial tests had not been used to quantify the risk of planting tuber seed with a known quantity of pathogen DNA on the seed.

The objectives of this study were to evaluate the importance of seed tuber-borne inoculum, as measured by tuber peel pathogen DNA levels and by visual disease assessment, in determining disease outcomes in progeny plants of cultivars Russet Burank and Innovator, two important processing varieties. Models were developed to determine the significance of relationships between pathogen inoculum on seed tubers and disease in progeny plants.

\section{Materials and Methods}

Selection of tuber seedlots. Seed tubers were sourced from commercial seedlots with wide variation in levels of tuber disease. All tubers were of equivalent physiological age and stored at $4{ }^{\circ} \mathrm{C}$ for 4 to 5 months prior to selection and planting. Cultivars Russet Burbank (2010, 80 tubers) and Innovator (2011, 140 tubers; 2012, 110 tubers) were examined. Both varieties are moderately resistant to common and powdery scab and moderately susceptible to black scurf $(13,15,35)$. Russet Burbank is moderately susceptible to Spongospora root galling with no published rating available for Innovator; however, one of its parents, 'Shepody,' is regarded as extremely susceptible to root galling (23). 
Visual disease assessment of seed tubers. Each tuber was visually assessed for black scurf, powdery scab, and common scab symptoms prior to planting, and assigned a disease tuber surface cover score ranging from 0 to 6 ( 0 : no visible disease on tuber surface, 0.5 : $<1 \%, 1: 1$ to $<5 \%, 2: 5$ to $<10 \%, 3: 10$ to $<30 \%, 4: 30$ to $<50 \%, 5: 50$ to $<70 \%, 6: 70$ to $100 \%$ tuber surface affected). The percentage tuber coverage was estimated from the mid values of these score ranges (39).

DNA quantification of pathogens on seed tubers. Following visual assessment, tuber peel was analyzed for $R$. solani AG3, $S$. subterranea, and $S$. scabies DNA content using qPCR. Each seed tuber was cut in half, with one half retained for planting. The other tuber half was completely peeled $(\sim 5 \mathrm{~mm}$ peel depth) with a sterilized kitchen peeler and the peel sample $(\sim 5 \mathrm{~g})$ dried at $40^{\circ} \mathrm{C}$ for 48 h. Individual samples were double bagged and stored at room temperature (for up to 1 week) prior to qPCR analysis.

Quantitative PCR (qPCR) of seed tubers. DNA extraction and qPCR was undertaken as a commercial service provided by Root Disease Testing Service (RDTS, SARDI, Adelaide, SA Australia) (24). qPCR used TaqMan Minor Groove Binder (MGB) probes (Applied Biosystems, Foster City, CA) performed on ABI PRISM $7900 \mathrm{HT}$ as described previously (26). The test for $R$. solani AG3 was designed by Diana Hartley (CSIRO Ecosystem Sciences, Canberra) using AG3F/AG3R primers (AG3F: 5'-AGTTTGGTT GTAGCTGGTCTATTTATGTA-3', AG3R: 5'-GAGTAGACAGAA GGGTTCAATGAGTT-3'), and AG3 probe 5'-6FAM-TGTCTC ACAAGTTCACAGGT-3'. For S. subterranea, assays amplified fragments from the ribosomal ITS 1 region using the previously defined primers (Spo10, Spo11) and probe (21). For S. scabies, a region from the thaxtomin A biosynthesis gene was amplified using CSF/CSR primers (CSF: 5'-ACGTCCGTAACCTTCGTCTG3', CSR: 5'-ATAGCGGCTGAGTTCGTTGT-3') and CS probe designed by Michael Tavaria (Applied Biosystems, Melbourne) $5^{\prime}$ 6FAM-CACGACTCCAGCGTC-3'. Quantitative data for each sample were determined by comparison to a serial dilution of pathogen DNA of known concentration.

Planting environment, setup, and experimental design. Planting in all three pot trials occurred in November (late spring), in New Town, Tasmania (GPS coordinates: 147 $17^{\prime} 57.21^{\prime \prime}$ E, $\left.42^{\circ} 51^{\prime} 24.55^{\prime \prime} \mathrm{S}\right)$ of the respective year $(2010,2011,2012)$ with pots placed outdoors in a randomized design, subject to natural spring/summer temperature variations. The tuber piece retained for planting was further halved, creating two representative seed pieces that were each hand-planted (150 to $180 \mathrm{~mm}$ depth) into separate $20 \mathrm{~cm}$ diameter pots $(2010,160$ pots in total; 2011, 280 pots; 2012, 220 pots). The potting mix (1 part course sand, 1 part peat, 8 parts composted pine bark; $\mathrm{pH}$ 6.0) was tested by qPCR prior to planting (24) and determined free of detectable DNA of the three pathogens of interest. During plant establishment, prior to emergence, limited irrigation was applied to maintain moist soil. After emergence, irrigation was applied at two to three day intervals, with additional irrigation when required. Soil moisture was managed to enable thorough wetting and drying to encourage multiple disease development $(10,37,40)$. No pesticides were applied throughout the trials.

Assessment of root galling and stolon pruning. In the 2011 and 2012 trials at 12 weeks after planting, one of the duplicate pots from each pair was assessed for root galls, symptomatic of $S$. subterranea root infection, and stolon pruning, symptomatic of $R$. solani AG3 infection. Soil was allowed to dry so that it could be easily separated from the roots and stolons without damaging these plant parts. Any excess soil was gently removed in running water. A root galling score per plant was determined using a 0 to 4 visual rating scale modified from that of van de Graaf and colleagues (37); $0=$ no galls; $1=1$ to 2 galls; $2=3$ to 10 galls, most $<2 \mathrm{~mm}$ in diameter; $3=>10$ galls, some $>2 \mathrm{~mm}$ in diameter; $4=$ most major roots with galls, some or all $>4 \mathrm{~mm}$ in diameter. The number of root galls per plant was also counted. Stolon pruning was assessed as the percentage of stolons per pot showing severe girdling and dieback and the presence of stem canker was recorded (3).
Assessment of tuber disease at harvest. Tubers were harvested at plant senescence and stored at $4^{\circ} \mathrm{C}$ for approximately 1 to 2 weeks prior to disease assessment. Tubers were washed and each tuber ( $>4 \mathrm{~g}$ ) scored ( 0 to 6 ) for the three tuber diseases (common scab, powdery scab, and black scurf) as described earlier. An average score and percentage tuber coverage was obtained per pot. The proportion of tubers with no visible lesions per pot was also recorded (39).

Statistical analysis and modeling. For each of the diseases, a modeling strategy was developed to investigate whether an association could be found between the DNA status and/or visual score of disease on the seed tuber and disease in the progeny tubers (black scurf, common scab, powdery scab), progeny stolons (stolon pruning), or with progeny roots (root galling). Where one of DNA or visual score was a successful predictor, it was dropped and the analysis repeated to see if the second predictor was significant. Further, for powdery scab, relationships between galling and progeny tuber disease were established.

Initially, the CTREE function of the PARTY library in R (25) was used to conduct recursive partitioning (14). This estimates a regression relationship by binary recursive partitioning in a conditional inference framework. Essentially, it splits the outcome variable (e.g., tuber disease) in an optimal way using the explanatory variables (seed tuber DNA levels or visual scores). Each split identified by the CTREE function is always significant. This approach attempts to find the "best" model and was used to identify cut points (where valid) for further modeling.

Then, receiver operating curves (ROCs) (18) were constructed using the ROCR package in R $(25,29)$. In each ROC plot, the estimated true positive (tp) rate is plotted on the vertical axis while the estimated false positive ( $\mathrm{fp}$ ) rate is plotted on the horizontal axis. The estimated tp rate is the proportion of samples with the pathogen DNA score being above a particular cut point given that the sample is in the infected population. The estimated fp rate is the proportion of samples in which the pathogen DNA score is above the same cut point but the sample is not in the infected population. In each case, 100 bootstrapped samples were used to calculate $95 \%$ CI for the ROC.

The aim of the ROC plot is to examine the relationship of the cut-points to the proportion of tps and fps. Ideally, where a predictor is a useful one, the curve rises rapidly to the top left corner and then flattens to follow the top of the plot. In the case where a predictor is not informative, the curve follows a diagonal line from the bottom left to the top right. The areas under the ROCs (AUC) were calculated to provide an indication of the test performance regardless of the selected cut point. The AUC can range from 0.5 to 1.0; those tests with areas closer to 0.5 have little discriminatory power, whereas those tests with areas closer to 1 are good discriminators. The AUC can also be interpreted as the average probability of correctly predicting a positive case across all possible cut points of the predictor. A rule of thumb is that a test with an AUC greater than 0.9 has high accuracy, while 0.7 to 0.9 indicates moderate accuracy, 0.5 to 0.7 low accuracy, and 0.5 a chance result (12). Comparisons of AUC were done by bootstrapping the curves using the roc.test function in the pROC library in $\mathrm{R}(27)$.

\section{Results}

Over the 3 years of this case study, the diseases that presented in the seed tubers and progeny tubers were powdery scab, black scurf, and common scab. Galling from $S$. subterranea infection in roots and stolon pruning from $R$. solani AG3 infection were also recorded. Exploratory analysis of the data for tuber disease (Figs. 1-3) indicated that there were no significant effects of cultivar on the disease outcomes assessed. Thus, data from both Russet Burbank and Innovator were pooled to provide a larger data set, with each of the key diseases then modeled separately. Root galling and stolon pruning (Figs. 4-6) were measured in the 2011 and 2012 trials with Innovator only.

Pathogen DNA and visual disease scores of seed tubers were significantly associated with tuber disease of the progeny tubers for 
R. solani AG3 and black scurf $(P<0.001$, Fig. $1 \mathrm{~A}$ and B) and $S$. scabies and common scab $(P=0.004$, Fig. $2 \mathrm{~A} ; P<0.001$, Fig. 2B). Recursive partitioning identified two significant DNA cut points (Fig. 1A and $\mathrm{C}$ and Fig. 2A and $\mathrm{C}$ ) and the importance of visual status of the seed tuber (Fig. $1 \mathrm{~B}$ and $\mathrm{C}$ and Fig. 2B and C). At higher pathogen DNA levels ( $>17,260 \mathrm{pg} R$. solani AG3 or $>12,453 \mathrm{pg}$ S. scabies) and where positive disease scores were made, the resultant tuber disease was greater. The high AUC values (Figs. 1D and 2D) of 0.97 for both $R$. solani AG3-black scurf and S. scabies-common scab, and an associated tight $95 \%$ CI, suggests the pathogen DNA tests provided a highly accurate discriminator of resultant tuber disease.

In contrast, neither amount of S. subterranea DNA nor visual disease status of the seed tuber had a significant predictive effect $(P>0.05)$ on powdery scab tuber surface cover disease in the progeny. To establish a relationship, we modeled a simplified outcome; namely, the presence/absence of tuber disease in the progeny, as a function of the visual status of the seed tuber (Fig. 3A). This model showed a significant effect $(P<0.001)$, indicating that a seed tuber with a visual score $>0$ would correspond to a greater chance of disease in the progeny tubers. Indeed, 60\% (110/183) of the pots produced tuber disease from visually infected seed tubers, whereas only $24 \%(32 / 134)$ of the pots recorded disease from symptomless seed tubers (Fig. 3A). A lack of a significant DNA cut point (Fig. 3B) and an AUC (Fig. 3C) produced for S. subterranea-powdery scab of 0.72 , with associated larger $95 \%$ CIs, suggested the pathogen DNA tests provided only a moderately accurate discriminator of resultant tuber disease.

We compared the models and ROCs for the three pathogens and tuber diseases above by using bootstrapping to compare their AUC
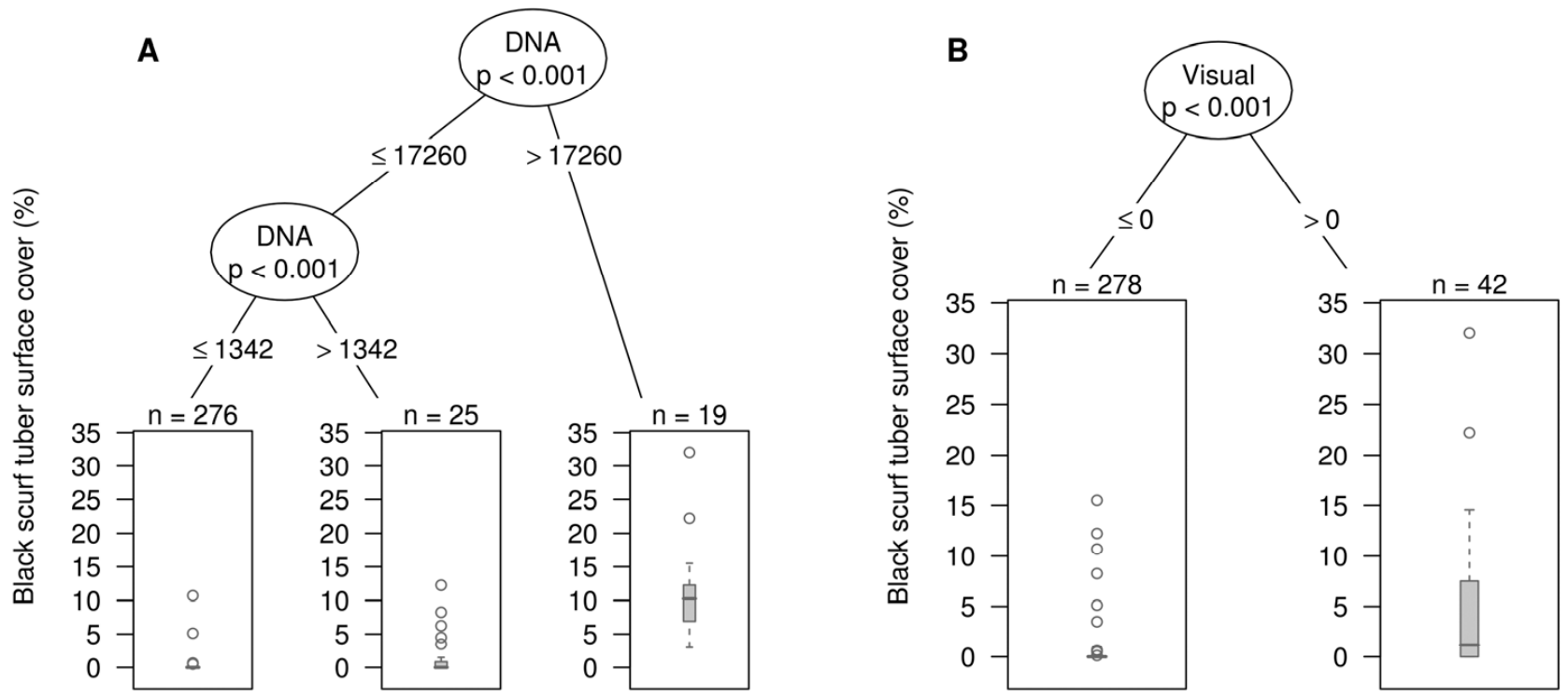

C

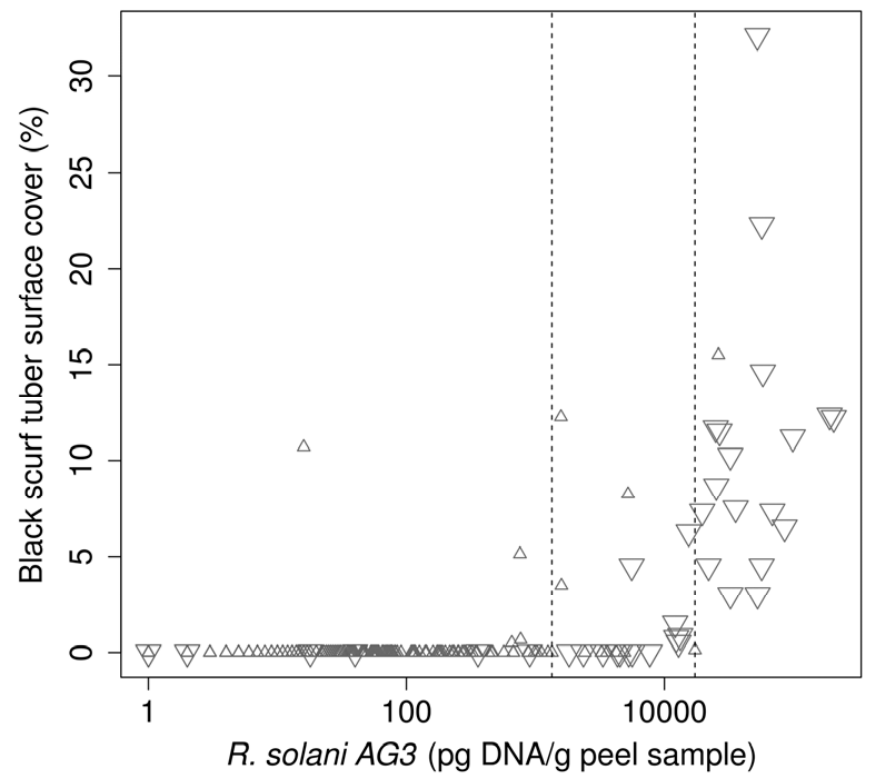

D

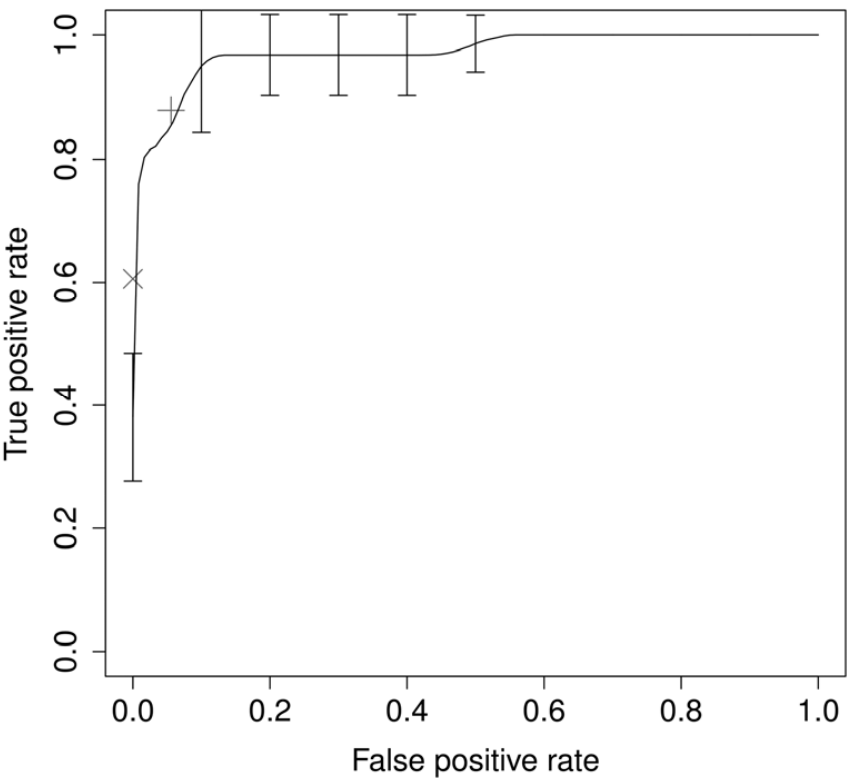

Fig. 1. Effect of seed tuber inoculum estimated by visual disease and Rhizoctonia solani AG3 DNA concentration on black scurf in progeny tubers. In A, recursive partitioning shows a significant association of pathogen DNA level with the black scurf tuber surface cover \%. In B, after excluding DNA, recursive partitioning detects a significant association of the visual status of seed tuber with black scurf tuber cover \%. In C, black scurf tuber surface cover \% is plotted against $R$. solani AG3 (pg DNA/g peel sample), showing cut points from the recursive partitioning indicated by vertical dashed lines; small triangle for visual $=0$, large inverted triangle for visual $>0$. In $\mathbf{D}$, bootstrapped receiver operating curve for disease using DNA level as a predictor of disease in progeny, $95 \%$ confidence intervals, and cut points shown as symbols: +: DNA = $1342 ; \mathrm{x}$ : DNA $=17,260(n=320)$. The mean AUC is 0.973 with $95 \% \mathrm{Cl} 0.930,0.995$. 
(27). Both $R$. solani AG3 and $S$. scabies DNA levels were highly accurate predictors of black scurf (Fig. 1D) and common scab (Fig. 2D), respectively, with no significant difference $(P=0.99)$ between their AUCs. Both these pathogens were significantly $(P<0.001)$ better predictors of disease in progeny tubers than that of $S$. subterranea DNA level in predicting powdery scab (Fig. 3C) as determined by comparison of their AUCs.

Both visual score $(P<0.01$, Fig. 4A) and pathogen DNA level $(P=0.014$, Fig. 4B) of seed tubers had significant predictive effects on the production of root galls in the progeny plants. While a positive visual score on the seed tuber correlated with increased root galling in the progeny, analysis detected a further significant split, whereby symptomless seed tubers having a pathogen DNA level ( $>22,345 \mathrm{pg}$ S. subterranea DNA/g peel sample) correlated with greater $(P<0.001)$ root galling than symptomless seed tubers with a lower pathogen DNA level (Fig. 4A). After excluding visual effects, recursive partitioning identified two significant pathogen DNA cut points $(>21,110$ and $>31,326 \mathrm{pg}$ S. subterranea DNA/g peel sample), above which greater root galling in the progeny plants occurred (Figs. 4B and C). The AUC (Fig. 4D) for S. subterranea-root galling was 0.83 , which suggested the DNA tests provided a moderately accurate prediction of root galling risk.

The number of root galls $(P<0.001$, Fig. 5A) was associated with powdery scab tuber disease $(\%)$ in the progeny tubers. Recursive partitioning identified a significant cut point of seven galls per plant; if gall number exceeded that number, then greater tuber powdery scab was likely to occur (Figs. 5A and B). The AUC (Fig. $5 \mathrm{C})$ for root galling-tuber disease of 0.76 suggested the gall number provided a moderately accurate discriminator of resultant tuber powdery scab.
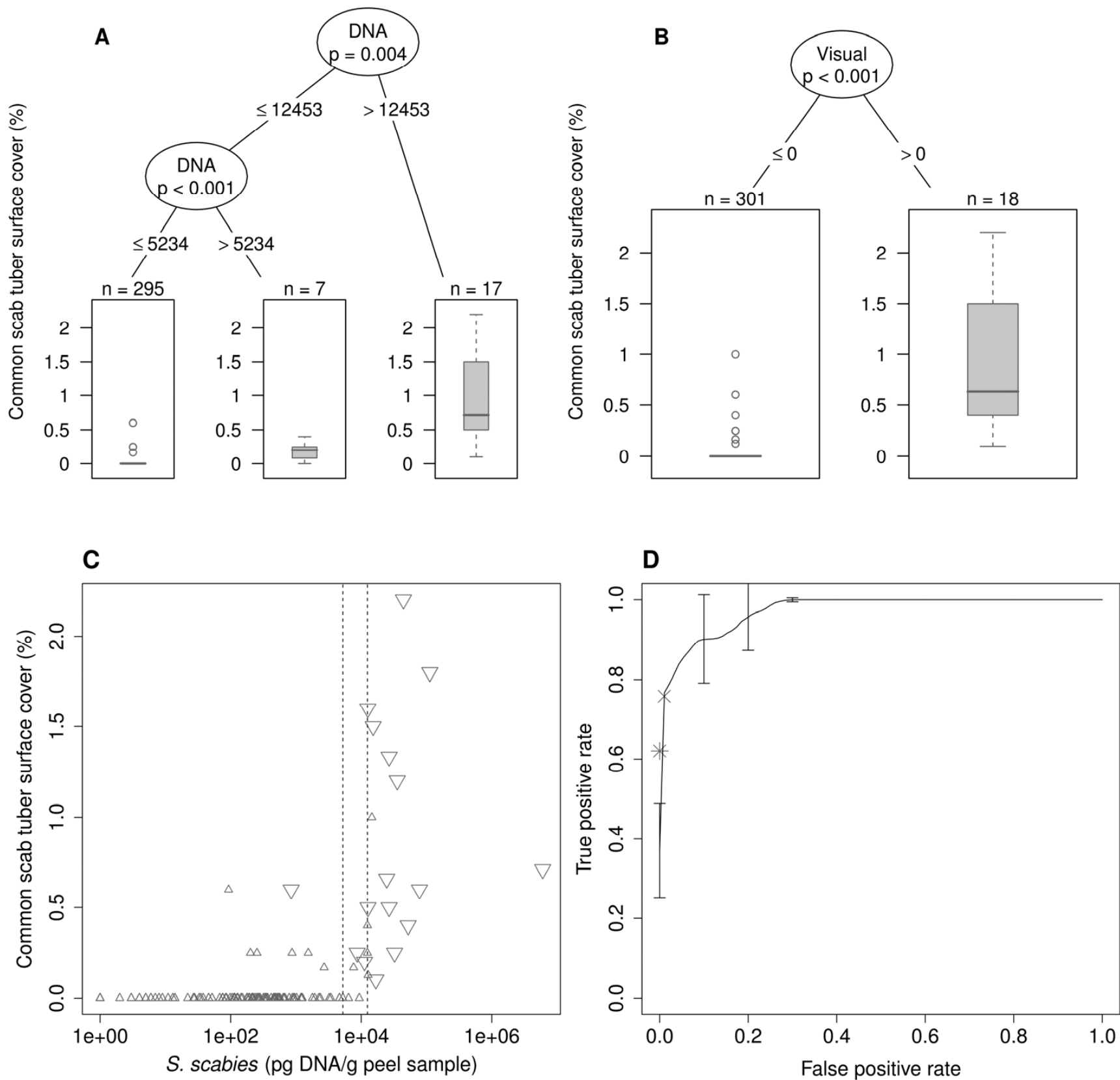

Fig. 2. Effect of seed tuber inoculum estimated by visual disease and Streptomyces scabies DNA concentration on common scab in progeny tubers. In A, recursive partitioning shows a significant association of pathogen DNA level with the common scab tuber surface cover \%. In B, after excluding DNA, recursive partitioning detects a significant association of the visual status of seed tuber with common scab tuber surface cover \%. In C, common scab tuber surface cover \% is plotted against $\mathrm{S}$. scabies (pg DNA/g peel sample), showing cut points from the recursive partitioning indicated by vertical dashed lines; small triangle for visual $=0$, large inverted triangle for visual $>0$. In $\mathbf{D}$, bootstrapped receiver operating curve for disease using DNA level as a predictor of disease in progeny, $95 \%$ confidence intervals, and cut points shown as symbols: $\times$ : DNA $=5234 ;$ * $:$ DNA $=12,453(n=319)$. The mean AUC is 0.974 with $95 \% \mathrm{Cl} 0.951,0.993$. 

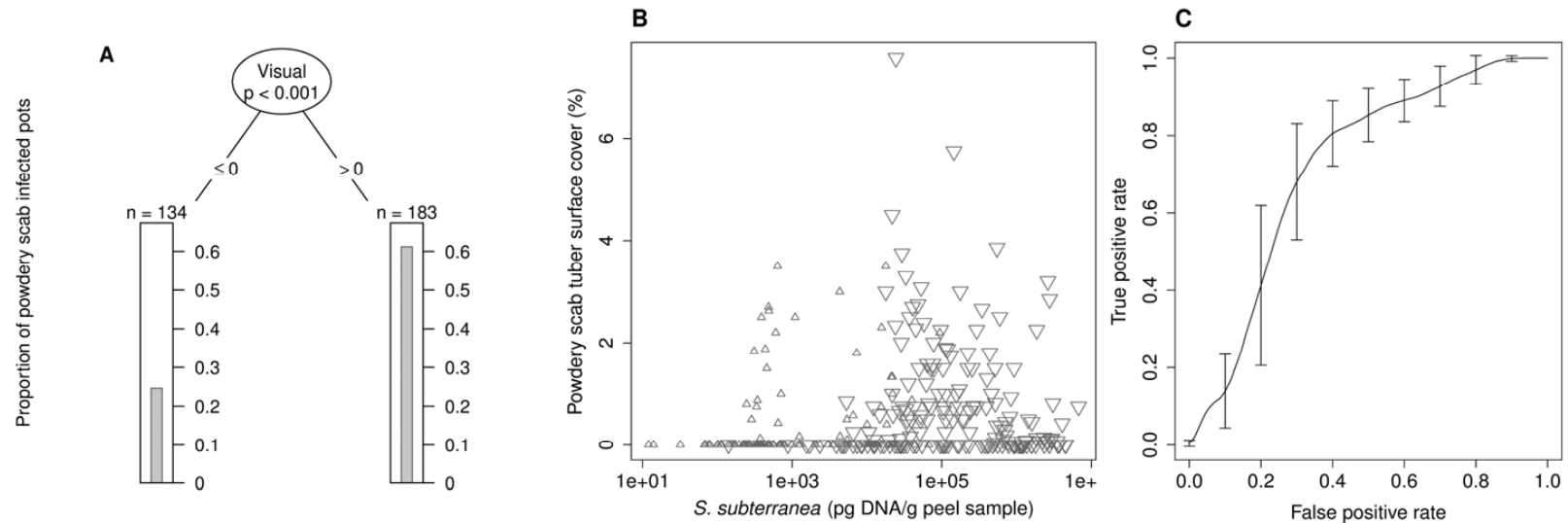

Fig. 3. Effect of seed tuber inoculum estimated by visual disease and Spongospora subterranea DNA concentration on powdery scab in progeny tubers. Recursive partitioning did not detect a significant association of pathogen DNA level or visual status of seed tuber with powdery scab surface cover \%. However, in A, simplified recursive partitioning detected a significant association of the visual status of seed tuber on the proportion (presence/absence) of powdery scab infected pots in the progeny; i.e., progeny disease was more often present with non-zero visual scores of the seed tuber. In B, powdery scab tuber surface cover \% is plotted against $S$. subterranea (pg DNA/g peel sample); small triangle for visual $=0$, large inverted triangle for visual $>0$. In $\mathbf{C}$, receiver operating curve for presence/absence of disease using DNA level as a predictor of disease in progeny $(n=319)$. The mean AUC is 0.72 with $95 \% \mathrm{Cl} 0.664,0.770$.

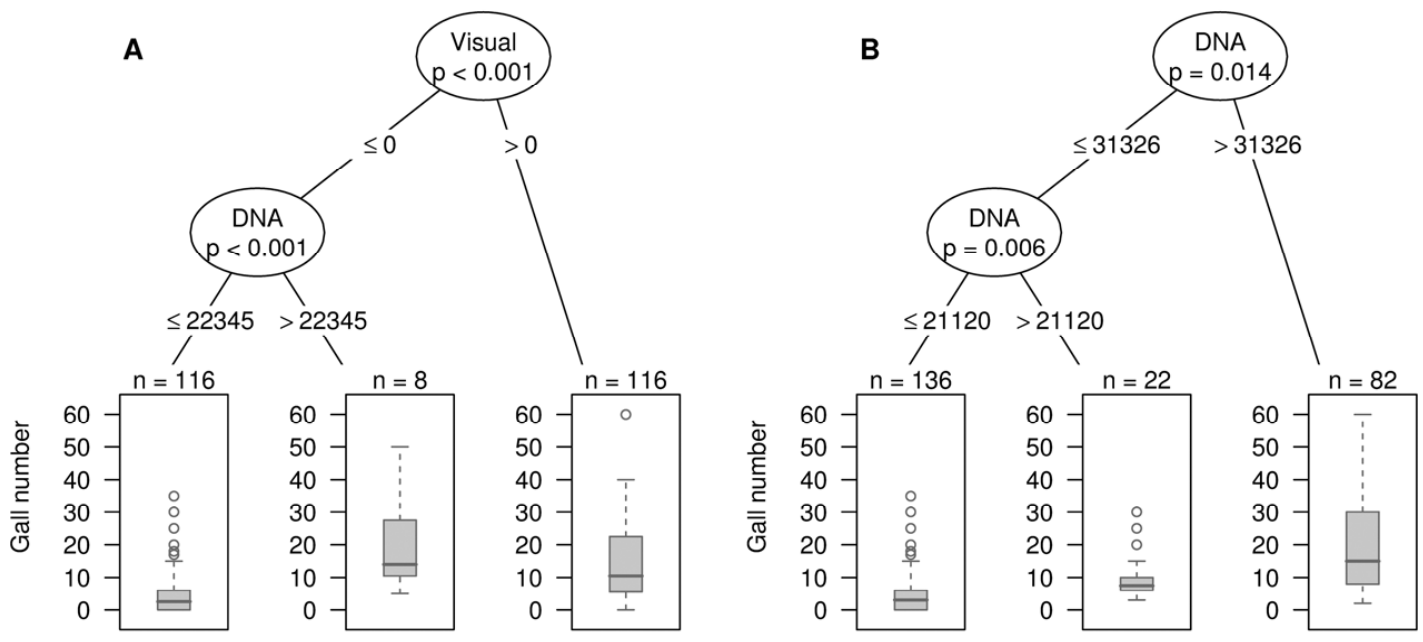

C

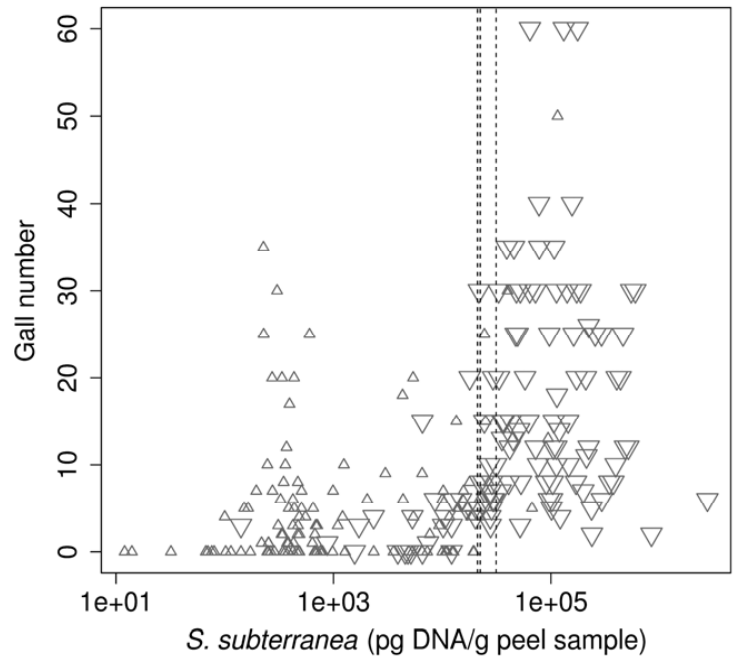

D

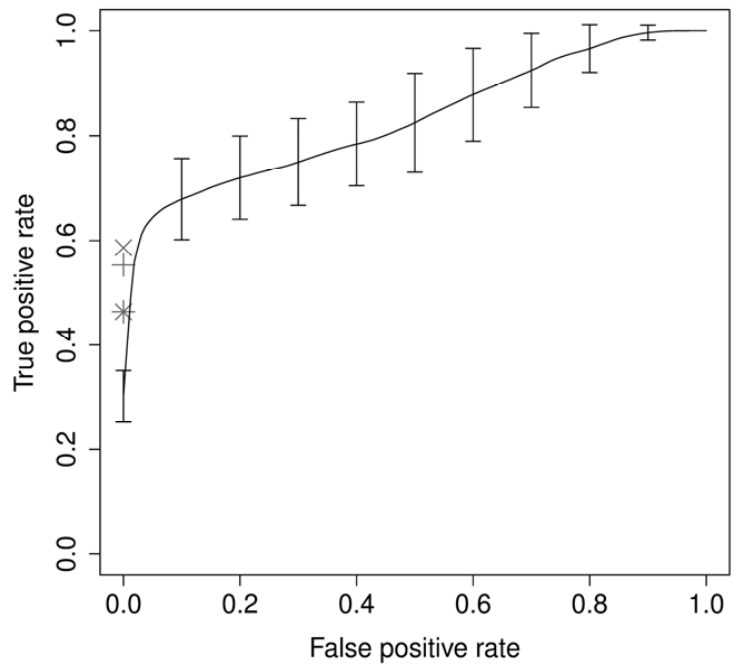

Fig. 4. Effect of seed tuber inoculum estimated by visual disease and Spongospora subterranea DNA concentration on root galling in progeny plants. In A, recursive partitioning shows a significant association of the visual status and the pathogen DNA level of the seed tuber with the gall number. In $\mathbf{B}$, that after excluding visual status, recursive partitioning detects a significant association of the DNA level of seed tuber with root gall number. In C, gall number is plotted against $S$. subterranea (pg DNA/g peel sample), showing cut points from the recursive partitioning indicated by vertical dashed lines; small triangle for visual $=0$, large inverted triangle for visual $>0$. We calculated ROCs for at least $1,2, \ldots, 30$ galls and calculated the area under each of these curves. The maximum area was obtained from the curve predicting at least 2 galls. In D, bootstrapped receiver operating curve for the presence of at least 2 galls using DNA as a predictor of galls, $95 \%$ confidence intervals, and cut points shown as symbols: $\times$ : DNA = 21,120; + : DNA $=22,345 ;$; $:$ DNA $=31,326(n=240)$. The AUC is 0.833 with $95 \% \mathrm{Cl} 0.774,0.878$. 
Comparing the models and ROCs generated for powdery scab and root galling using their AUCs (27) indicated that the association between seed tuber pathogen DNA level and root galling production (Fig. 4D) was significantly stronger $(P=0.002)$ than that between seed tuber pathogen DNA level and tuber progeny powdery scab (Fig. 3C).

Both pathogen DNA level $(P<0.001$, Fig. 6A) and visual score $(P<0.001$, Fig. 6B) of seed tubers had significant effects on the proportion of pruned stolons in the progeny plants. Recursive partitioning identified two significant pathogen DNA cut points, (Figs. $6 \mathrm{~A}$ and $\mathrm{C}$ ) above which greater stolon pruning occurred. Where the visual status of the seed tuber was higher (visual score $>0.5$, Fig. $6 \mathrm{~B})$, increased stolon pruning was recorded in the progeny. The AUC (Fig. 4D) for $R$. solani AG3-stolon pruning was 0.92, which suggested the DNA tests provided a good prediction of resultant stolon pruning. Infrequent occurrence of stem canker caused by $R$. solani infection of the potato stem was noted. These were always associated with higher pathogen DNA levels and visual scores in the seed tuber, but there were insufficient data points for analysis.

\section{Discussion}

Tracking of seed tubers as individual units in this case study has enabled the production of validated and scientifically rigorous data that quantifies the role of seed tuber-borne inoculum, for the pathogens and cultivars used in these experiments, in inducing root, stolon, and tuber disease in progeny plants. Parameters that define the health of the seed tuber, pathogen content by qPCR and visual tuber disease score, were both associated with the production of disease in the progeny plants. This reiterates a significant role for seed health in managing these significant potato diseases.

While previous work has sought to define the relationship between seed tuber health and subsequent disease in pathogen-free soil, this present study provides new evidence and analysis techniques to complement previous studies. The statistical modeling approach provides DNA cut points, including specific quantitative numbers that can be used (for the cultivars presented in this case study) to generate disease risk profiles for planting potato seed tubers carrying varying pathogen loads into pathogen-free soil. For the present case study, Russet Burbank and Innovator are globally important cultivars and powdery scab and root galling, common scab, black scurf, and stolon pruning are economically important and common diseases worldwide.

For two of the three diseases reported here, the combination of both visual disease assessment and pathogen DNA data from the seed tuber have been strongly associated with progeny disease outcome. In the case of $R$. solani, there was a strong association of both pathogen DNA and visual disease assessment of the seed tuber with stolon pruning, stem cankering, and resultant black scurf tuber disease. This strongly supports previous findings where visually infected seed resulted in increased subterranean stem and stolon lesions, girdling, and canker $(3,34)$ and tuber disease $(3,8,34)$. The DNA associations generated by modeling (Fig. 1A) also produced potential threshold levels that may be a useful tool in classifying the seed tuber as suitable to plant. From a practical perspective, growers would benefit from planting tubers that had no visual disease present; if only disease-infested seed tubers were available, then a fungicide seed treatment would be highly recommended $(8,33)$ to minimize the likelihood of subsequent tuber disease.

In the case of common scab, we also report a strong relationship between both high pathogen DNA and high visual disease scores of the seed tuber with increased disease in progeny tubers. These findings support the work of some researchers $(38,39)$ and contradict others $(1,19)$. Common scab is influenced by a range of factors, including cultivar and environmental conditions. Parameters reported in the field trials of Lapwood (19), high soil moisture and presence of high soil inoculum, were likely to have negated the role of seedborne inoculum in some studies. The work reported by Adams (1) indicated extremely low tuber disease in the progeny, so differentiating a significant treatment effect (seedborne inoculum) may have been difficult. Our results created an optimized pot environment conducive to disease, and removed the complication of soilborne inoculum in the field such that the role of seed tuberborne inoculum could be studied in isolation.

In the case of powdery scab, we report that only a simplified model could be generated linking the visual status of the seed tuber with absence/presence of tuber disease in the progeny. Additionally, there was no relationship established between pathogen DNA detected on the seed tuber and progeny tuber disease. This is reflected in the low AUC and higher variances, and larger 95\% confidence intervals (Fig. 3C), compared with the better associations developed for both black scurf (Fig. 1D) and common scab (Fig. 2D). Our conclusions are that powdery scab seed tuber-borne inoculum is not a good predictor of progeny tuber disease, for the cultivars and trial conditions used. This supports the findings of some researchers $(6,16)$ yet contradicts others $(10,22)$. Powdery scab is also heavily influenced by cultivar resistance (13) and environmental conditions, with tuber disease favored by wet and cool soil conditions (soil temperature range: 9 to $\left.17^{\circ} \mathrm{C}\right)(28,36)$. In these trials, disease conducive soil moisture conditions were maintained; however, fluctuating temperatures as a result of pot culture may have led to suboptimal soil temperatures for powdery scab development. The use of cultivars with moderate resistance to powdery scab may have also influenced efficacy of transmission from seed tuber to
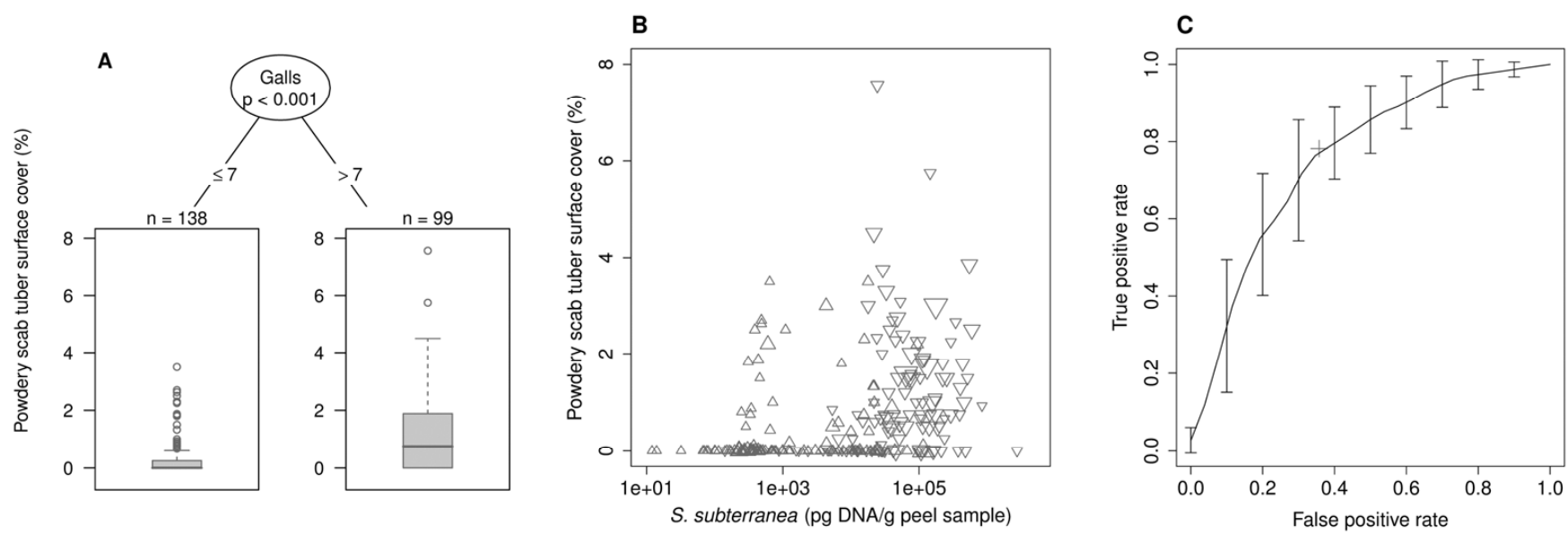

Fig. 5. Relationship between root galling and powdery scab disease in progeny tubers. In $\mathbf{A}$, recursive partitioning shows a significant association of gall number with tuber disease in the progeny. In B, powdery scab surface cover (\%) is plotted against the Spongospora subterranea DNA content of the seed tuber. Symbols are sized in proportion to gall number, triangle for visual $=0$, inverted triangle for visual $>0$. In C, bootstrapped receiver operating curve for the presence of tuber disease using the number of galls as a predictor, $95 \%$ confidence intervals, and the cut point shown as a symbol: + : no. of galls $=7(n=240)$. The mean AUC is 0.758 with $95 \% \mathrm{Cl} 0.701,0.811$. 
progeny. Future work in this could examine additional cultivars and alternate infective conditions to conclusively determine the role of seed tuber-borne inoculum in powdery scab disease.

While there are a number of studies on the impact of seed tuberborne inoculum on powdery scab disease in progeny tubers, very few have studied the impact of seedborne inoculum on root infection and gall production. Here we show a strong significant association between seedborne inoculum (both visual assessment and pathogen DNA content) and root gall production. This is particularly interesting given the weaker association found between seedborne inoculum and powdery scab in tubers. Spongospora root infection has a wider temperature tolerance range to disease induction (soil temperature range: 11 to $\left.25^{\circ} \mathrm{C}\right)(17,37)$. This suggests root infection occurs more reliably than tuber infection under warmer temperatures.

Of note was the production of significant root gall numbers from symptomless (or visually clean) tubers, on some occasions (Fig. 4A). Further, qPCR was able to detect the higher DNA levels (from symptomless seed tubers) that were more likely to promote galling than symptomless seed tubers with low DNA readings. Others have reported detection of pathogens present on seed tubers as contaminants without obvious symptoms $(4,36)$ and there are reports of powdery scab following planting of visually "clean" seed into soil with low inoculum pressures $(28,36)$, suggesting accurate pathogen inoculum detection on seed is essential for quantifying potential disease. In these cases, more rigorous pathogen detection tools such as qPCR may provide a superior means of determining seed tuber health to traditional visual assessment.

The interaction between root and tuber diseases caused by $S$. subterranea is not necessarily a simple one. Previous researchers have found that root infection was usually related to tuber infection, although exceptions existed $(7,9)$. When studying 14 cultivars, Falloon and colleagues (9) reported that cv. Swift had very low levels of tuber infection in the field, but had high numbers of root zoosporangia and root galls in the glasshouse. Likewise, a study of 19 cultivars (7) indicated the majority of cultivars tested showed
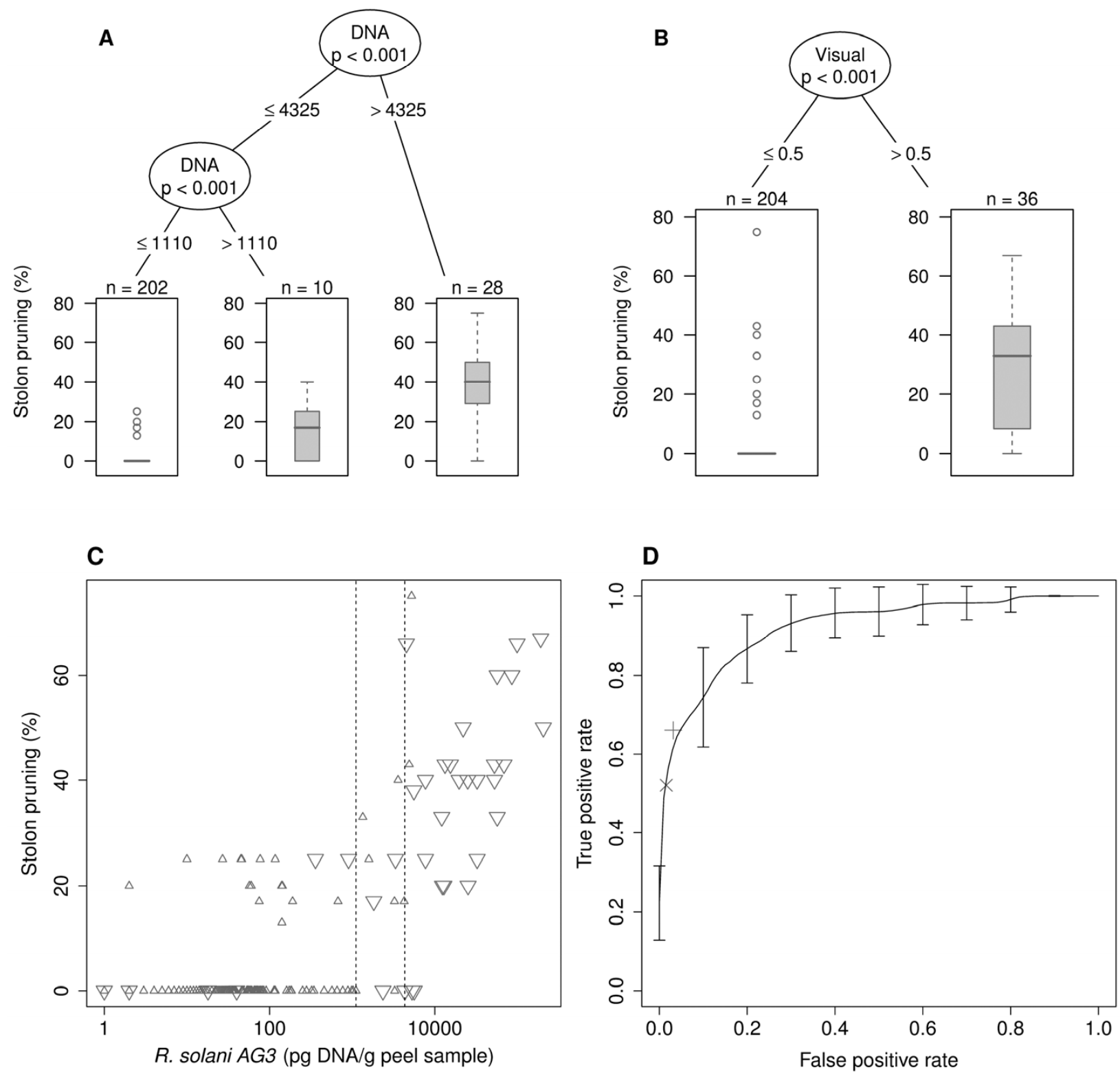

Fig. 6. Effect of seed tuber inoculum estimated by visual disease and Rhizoctonia solani AG3 DNA concentration on stolon pruning in progeny plants. In A, recursive partitioning shows a significant association of pathogen DNA level with the stolon pruning \%. In B, after excluding DNA, recursive partitioning detects a significant association of the visual status of seed tuber with stolon pruning $\%$. In C, stolon pruning \% is plotted against $R$. solani AG3 (pg DNA/g peel sample), showing cut points from the recursive partitioning indicated by vertical dashed lines; small triangle for visual $=0$, large inverted triangle for visual $>0$. In $\mathbf{D}$, bootstrapped receiver operating curve for non-zero stolon pruning (i.e., presence/absence) using DNA level as a predictor, 95\% confidence intervals, and cut points shown as symbols: +: DNA = 1110; $x$ : DNA = 4325 ( $n=240)$. The mean AUC is 0.92 with $95 \% \mathrm{Cl} 0.871,0.957$. 
similar levels of susceptibility to powdery scab on tubers and in roots; however, cv. Russet Burbank was an exception, with low infection on tubers but with root infection levels similar to cultivars with high tuber susceptibility. Others have found no correlation between the occurrence of galls on roots and powdery scab on tubers of the same plants (37). Our work with Innovator suggests that root galling provides a moderately accurate association with tuber disease (Fig. 5C). It is quite probable that Innovator, which is reported to have moderate resistance to tuber infection (13), may have greater susceptibility to root galling, similar to that reported for Russet Burbank (23).

The use of clean or certified seed tubers is a recommended practice (2) that aids the control of many important seed tuber-borne potato diseases. The standard of certified seed tubers can vary from country to country with major differences between methodologies in accessing tubers for disease and in threshold levels of disease tolerances allowed (31). Additionally, visual assessments are subjective, meaning that assessments carried out in different countries are not always directly comparable. While visual assessments provide value in determining seed tuber health quality, the addition of new technologies, such as pathogen DNA quantification using qPCR as presented here, provide extra quantitative data. If universally adopted, this may improve comparison of global results.

\section{Acknowledgments}

We thank Iain Kirkwood for initial project conception and development and Philip Beveridge, Ann-Maree Donoghue, and Leonie White for the collection of tuber seedlot samples. The research presented is part of a multi-pronged research drive through the Australian Potato Research Program (Phase 2), funded by Horticulture Australia Limited using the processing potato industry levy and matched funds from the Federal Government. The University of Tasmania/Tasmania Institute of Agriculture has provided in-kind support.

\section{Literature Cited}

1. Adams, M. J., and Hide, G. A. 1981. Effects of common scab (Streptomyces scabies) on potatoes. Ann. Appl. Biol. 98:211-216.

2. Andrade, S. N., Contreras, M. A., and Castro, U. I. 2008. Effect of using certified and uncertified potato seeds on the yield and sanitary conditions of a potato crop. Agro. Sur. 36:63-66.

3. Atkinson, D., Thornton, M. K., and Miller, J. S. 2010. Development of Rhizoctonia solani on stems, stolons and tubers of potatoes I. Effect of inoculum source. Am. J. Pot. Res. 87:374-381.

4. Bouchek-Mechiche, K., Montfort, F., and Merz, U. 2011. Evaluation of the Sss AgriStrip rapid diagnostic test for the detection of Spongospora subterranea on potato tubers. Eur. J. Plant Pathol. 131:277-287.

5. Brierley, J. L., Sullivan, L., Wale, S. J., Hilton, A. J., Kiezebrink, D. T., and Lees, A. K. 2012. Relationship between Spongospora subterranea f.sp. subterranea soil inoculum level, host resistance and powdery scab on potato tubers in the field. Plant Pathol. 62:413-420.

6. Burnett, F. 1991. The Biology and Control of Powdery Scab (Spongospora subterranea) of Potatoes. University of Aberdeen, Aberdeen, UK

7. Eraslan, F., and Turhan, G. 1989. Studies on powdery scab of potato with special regard to the reactions of certain potato cultivars and clones. Z. Pflanzenkr. Pflanzenschutz 96:353-360.

8. Errampalli, D., and Johnston, H. W. 2001. Control of tuber-borne black scurf [Rhizoctonia solani] and common scab [Streptomyces scabies] of potatoes with a combination of sodium hypochlorite and thiophanatemethyl preplanting seed tuber treatment. Can. J. Plant Pathol. 23:68-77.

9. Falloon, R. E., Genet, R. A., Wallace, A. R., and Butler, R. C. 2003. Susceptibility of potato (Solanum tuberosum) cultivars to powdery scab (caused by Spongospora subterranea f. sp subterranea), and relationships between tuber and root infection. Australas. Plant Pathol. 32:377-385.

10. Falloon, R. E., Wallace, A. R., Braithwaite, M., Genet, R. A., Nott, H. M., Fletcher, J. D., and Braam, W. F. 1996. Assessment of seed tuber, in-furrow, and foliar chemical treatments for control of powdery scab (Spongospora subterranea f sp subterranea) of potato. New Zeal. J. Crop Hort. 24:341-353.

11. Fiers, M., Edel-Hermann, V., Chatot, C., Le Hingrat, Y., Alabouvette, C., and Steinberg, C. 2012. Potato soil-borne diseases. A review. Agron. Sustain. Dev. 32:93-132.

12. Fischer, J. E., Bachmann, L. M., and Jaeschke, R. 2003. A readers' guide to the interpretation of diagnostic test properties: clinical example of sepsis. Intensive Care Med. 29:1043-1051.

13. Genet, R. A., Braam, W. F., Wallace, A. R., and Falloon, R. 2011. Susceptibility of potato cultivars and gerplasm lines to powdery scab in New Zealand. In: 3rd European Powdery Scab Workshop, Boldern, Switzerland, 11-13 July.

14. Hothorn, T., Hornik, K., and Zeileis, A. 2006. Unbiased recursive partitioning: A conditional inference framework. J. Comput. Graph. Stat.
15:651-674.

15. HZPC. 2013. Innovator (Shepody x RZ -84 -2580): General production advice ware potatoes. Crowle, Scunthorpe, UK.

16. Keiser, A., Jaquiery, P. Y., and Merz, U. 2007. Infected seed into clean soil (field trials in Switzerland). In: 2nd European Powdery Scab Workshop, Langnau, Switzerland.

17. Kole, A. P. 1954. A contribution to the knowldge of Spongospora subterranea (Wallr.) Lagerh., cause of powdery scab of potatoes. Tijdschrift over Plantenziekten 60:1-65.

18. Krzanowski, W. J., and Hand, D. J. 2009. ROC Curves for Continuous Data. CRC Press, Boca Raton, FL.

19. Lapwood, D. H. 1972. The relative importance of weather, soil- and seedborne inoculum in determining the incidence of common scab (Streptomyces scabies) in potato crops. Plant Pathol. 21:105-108.

20. Lees, A. K., Brierley, J. L., Stewart, J. A., Hilton, A. J., Wale, S. J. Gladders, P., Bradshaw, N. J., and Peters, J. C. 2010. Relative importance of seed tuber and soilborne inoculum in causing black dot disease of potato. Plant Pathol. 59:693-702.

21. Maldonado, M. L. H., Falloon, R. E., Butler, R. C., Conner, A. J., and Bulman, S. R. 2013. Spongospora subterranea root infection assessed in two potato cultivars differing in susceptibility to tuber powdery scab. Plant Pathol. 62:1089-1096.

22. Merz, U., and Falloon, R. E. 2009. Review: Powdery scab of potatoIncreased knowledge of pathogen biology and disease epidemiology for effective disease management. Potato Res. 52:17-37.

23. Nitzan, N., Cummings, T. F., Johnson, D. A., Miller, J. S., Batchelor, D. L. Olsen, C., Quick, R. A., and Brown, C. R. 2008. Resistance to root galling caused by the powdery scab pathogen Spongospora subterranea in potato. Plant Dis. 92:1643-1649.

24. Ophel-Keller, K., McKay, A., Harding, R., Hall, B., Wicks, T., Wiechel, T., Crump, N., Shah, F., Marshall, J., and Falloon, R. 2009. DNA monitoring tools for soil-borne pathogens of potato. in: Australian potato research program final report to Horticulture Australia for project PT04016, I. Kirkwood, ed. Horticulture Australia, Sydney.

25. R Development Core Team. 2012. R: A language and environment for statistical computing. R Foundation for Statistical Computing. Vienna, Austria.

26. Riley, I. T., Wiebkin, S., Hartley, D., and McKay, A. C. 2010. Quantification of roots and seeds in soil with real-time PCR. Plant Soil 331:151-163.

27. Robin, X., Turck, N., Hainard, A., Tiberti, N., Lisacek, F., Sanchez, J.-C., and Mueller, M. 2011. pROC: an open-source package for R and S plus to analyze and compare ROC curves. BMC Bioinformatics 12 .

28. Shah, F. A., Falloon, R. E., Butler, R. C., and Lister, R. A. 2012. Low amounts of Spongospora subterranea sporosorus inoculum cause severe powdery scab, root galling and reduced water use in potato (Solanum tuberosum). Australas. Plant Pathol. 41:219-228.

29. Sing, T., Sander, O., Beerenwinkel, N., and Lengauer, T. 2005. ROCR: visualizing classifier performance in R. Bioinformatics 21:3940-3941.

30. Sparrow, L., and Wilson, C. 2012. Managing and monitoring viral and soilborne pathogens in Tasmanian potato crops. Pages 309-325 in: Sustainable Potato Production: Global Case Studies. Z. He, R. Larkin and W. Honeycutt, eds. Springer Netherlands.

31. Tegg, R. S., Corkrey, R., and Wilson, C. R. 2014. A comparison of potato seed tuber sampling strategies using visual and DNA analyses to estimate incidence of major seed tuber-borne pathogens. Eur. J. Plant Pathol. 139:353-361.

32. Tegg, R. S., Thangavel, T., Aminian, H., and Wilson, C. R. 2013. Somaclonal selection in potato for resistance to common scab provides concurrent resistance to powdery scab. Plant Pathol. 62:922-931.

33. Tsror, L. 2010. Biology, Epidemiology and Management of Rhizoctonia solani on Potato. J. Phytopathol. 158:649-658.

34. Tsror, L., and Peretz-Alon, I. 2005. The influence of the inoculum source of Rhizoctonia solani on development of black scurf on potato. J. Phytopathol. 153:240-244.

35. UNL. 2013. Cropwatch potato Education Guide - Russet Burbank. University of Nebraska, Lincoln (UNL).

36. van de Graaf, P., Lees, A. K., Wale, S. J., and Duncan, J. M. 2005. Effect of soil inoculum level and environmental factors on potato powdery scab caused by Spongospora subterranea. Plant Pathol. 54:22-28.

37. van de Graaf, P., Wale, S. J., and Lees, A. K. 2007. Factors affecting the incidence and severity of Spongospora subterranea infection and galling in potato roots. Plant Pathol. 56:1005-1013.

38. Wang, A., and Lazarovits, G. 2005. Role of seed tubers in the spread of plant pathogenic Streptomyces and initiating potato common scab disease. Am. J. Pot. Res. 82:221-230.

39. Wilson, C. R., Ransom, L. M., and Pemberton, B. M. 1999. The relative importance of seed-borne inoculum to common scab disease of potato and the efficacy of seed tuber and soil treatments for disease control. J. Phytopathol. 147:13-18.

40. Wilson, C. R., Tegg, R. S., Wilson, A. J., Luckman, G. A., Eyles, A., Yuan, Z. Q., Hingston, L. H., and Conner, A. J. 2010. Stable and extreme resistance to common scab of potato obtained through somatic cell selection. Phytopathology 100:460-467. 